Article

\title{
Numerical Study of the Drying of Cassava Roots Chips Using an Indirect Solar Dryer in Natural Convection
}

\author{
Merlin Simo-Tagne ${ }^{1,2, *} \mathbb{\infty}$, Ablain Tagne Tagne ${ }^{3}$, Macmanus Chinenye Ndukwu ${ }^{4}\left(\mathbb{D}\right.$, Lyes Bennamoun ${ }^{5} \mathbb{D}^{\text {, }}$ \\ Marcel Brice Obounou Akong ${ }^{3}$, Maryam El Marouani ${ }^{6}$ (D) and Yann Rogaume ${ }^{7}$ (D) \\ 1 INRAE, LERMAB, ERBE-F, 88000 Epinal, France \\ 2 Nancy-Metz Academy, 54035, 2 rue Philippe de Gueldres, 54000 Nancy, France \\ 3 Department of Science, University of Yaoundé I, Yaoundé P.O. Box 812, Cameroon; \\ tagneablain97@gmail.com (A.T.T.); marcelobounou@yahoo.fr (M.B.O.A.) \\ 4 Department of Agricultural and Bioresources Engineering, Michael Okpara University of Agriculture, \\ Umuahia P.M.B. 7267, Abia State, Nigeria; ndukwumcu@mouau.edu.ng \\ 5 Department of Mechanical Engineering, University of New Brunswick, 15 Dineen Drive, Fredericton, \\ NB E3B 5A3, Canada; lyes.bennamoun@unb.ca \\ 6 Department of Chemistry, College of Sciences, University of Hafr Al Batin, Hafr Al Batin 39524, Saudi Arabia; \\ melmarouani@uhb.edu.sa \\ 7 Université de Lorraine, INRAE, LERMAB, ERBE-F, 88000 Epinal, France; yann.rogaume@univ-lorraine.fr \\ * Correspondence: simotagne2002@yahoo.fr or Merlin.Simo-Tagne@ac-nancy-metz.fr; Tel.: +33-644-911-921
}

Citation: Simo-Tagne, M.; Tagne

Tagne, A.; Ndukwu, M.C.;

Bennamoun, L.; Obounou Akong, M.B.; El Marouani, M.; Rogaume, Y. Numerical Study of the Drying of Cassava Roots Chips Using an Indirect Solar Dryer in Natural Convection. AgriEngineering 2021, 3 , 138-19. https://doi.org/10.3390/ agriengineering 3010009

Received: 17 February 2021

Accepted: 5 March 2021

Published: 17 March 2021

Publisher's Note: MDPI stays neutral with regard to jurisdictional claims in published maps and institutional affiliations.

Copyright: (c) 2021 by the authors. Licensee MDPI, Basel, Switzerland. This article is an open access article distributed under the terms and conditions of the Creative Commons Attribution (CC BY) license (https:// creativecommons.org/licenses/by/ $4.0 /)$.

\begin{abstract}
In this work, an indirect solar dryer for drying cassava root chips was modelled and experimentally validated using the environmental conditions of Yaoundé in Cameroon and Yamoussoukro in Ivory Coast. The dryers were operational in natural convection mode. Resolution of the equations was achieved by finite differences and the 4 th order of Runge-Kutta methods. A model was proposed for performing heat and mass transfer using thermophysical properties of cassava roots, and the obtained results were satisfactory for all conditions, with moisture content difference of less than $0.2 \mathrm{~kg} / \mathrm{kg}$ between the experimental and theoretical results. The model showed that the core of the product takes more time to dry, which always prolongs the drying duration. The heat and mass transfer coefficients vary during the entire process of solar drying. The drying kinetics vary during the drying with values lower than $1.2 \times 10^{-4} \mathrm{~kg} /(\mathrm{kg} . \mathrm{s})$. The great gradients of humidity were observed in the thickness of the sample with a regular distribution of the temperature each drying time in the thickness of the sample.
\end{abstract}

Keywords: cassava roots; desorption isotherms; drying kinetics; heat and mass transfer; natural convection; solar dryer; Sub-Saharan Africa

\section{Introduction}

The challenges facing most developing countries, especially in Africa, is not what to produce but primarily how to process and preserve what is produced [1]. In 2009, Africa alone lost $25 \%$ of food produced, which constitute about 4.5 million metric tonnes of food produced in 2009 [2], and the trend continued unabated until this day. This volume of food losses is very huge, considering that most homes in Africa live on less than one dollar a day. This massive loss of food production occurs mostly during the crop season when there is always a glut in the market, and producers or farmers struggle to sell their product. Due to a lack of processing and preservation facilities, these products, if not sold, will be allowed to rot or fed to animals [3]. Cassava root is among the agricultural products that are losses sustained by farmers because cassava (Manihot utilisima Kunz.) root is a major staple food in most African countries and across Latin America and Asia because of their high carbohydrate value [4]. In most countries, cassava roots are processed into flakes, fufu, and cassava chips for direct consumption or utilization in industries for the production of cassava flour or feeds for animals [5]. However, the major critical step 
employed by farmers to preserve their product is drying. The unit operations involved in cassava processing includes harvesting the roots (Figure 1a) from the farm, washing, cutting, peeling, shredding or chipping (Figure 1b), and drying [6-8]. The drying of the cassava chips is essential for shelf life extension, secondary conversion, reduction in bulk weight, product packaging, ease of transportation, etc. However, drying consumes a lot of energy, due to the high initial moisture content of cassava tubers immediately after harvest. Drying can be achieved through the use of artificial industrial dryers or locally by making use of the abundant sun available, as it is done in most African countries [9]. However, the use of sun-drying to dry the chips exposes the cassava chips to contamination from impurities arising from dust, animal droppings, and possible rewetting from rainfall, which prolongs the drying periods $[10,11]$. In most cases, to safeguard the products from the above scenario, the processor (i.e., person processing the chips) has to be around to keep watch over the product, thereby splitting their time between, going to the farm and the market, and watching over the product, which is usually tedious. Therefore, solar drying has been suggested as the most cost-effective method to solve this problem [12-15].
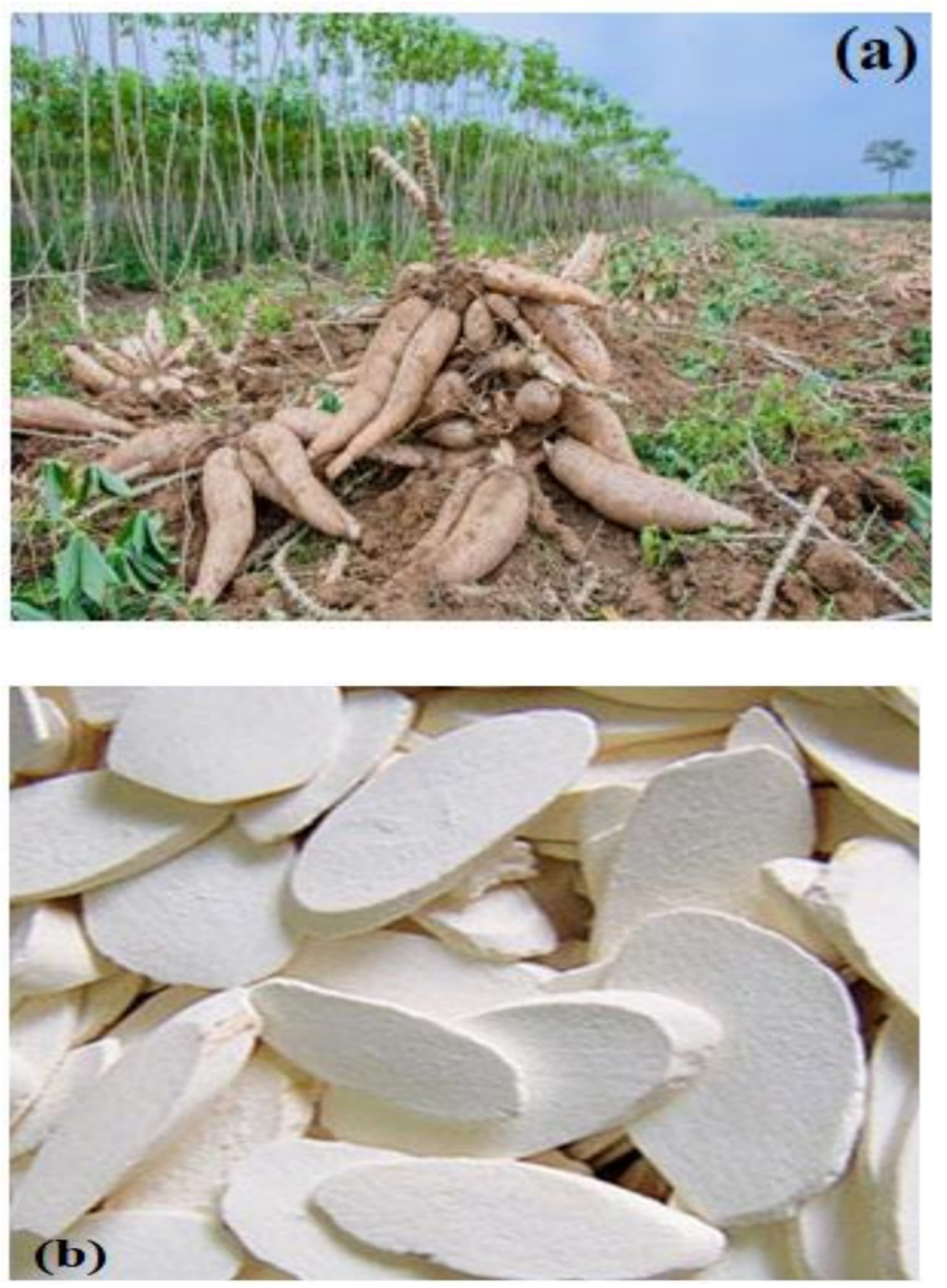

Figure 1. Some pictures of cassava roots. (a) Cassava roots with bark from plantations [16], (b) cassava roots chips without bark ready to be dried [17].

Solar dryer gives room for flexibility in the choice of the material and design based on the size of the enterprise and users' income level. Various designs can range from a simple solar cabinet dryer to indirect solar dryers and hybrids solar dryers equipped with supplementary assisted heat sources, such as thermal storage material, electricity, biomass heater, etc., to continue the drying process during the night or when the weather is not 
clement [18-24]. Additionally, Ndukwu et al. [25] and Bennamoun [26] have reviewed different solar dryer designs across the African continent and concluded that different designs are now available in Africa for both direct and indirect drying chamber designs. In addition, Chaudhari and Salve [27], in their review of different solar drying technology and designs, showed that the drying kinetics of several crops based on diffusion models has been studied for solar dryers of different kinds. However, what is lacking in most of the research is simulation models that will help in the future optimization of developed dryers for different products [24]. This will reduce the bulkiness and cost of experimentations and help in the standardization of solar dryer designs. Some researchers have developed some numerical simulation models to tackle these challenges in the African continent. For example, Bahnasawy and Shenanan [28] showed the sudden effect of airflow rate on the initial moisture level when simulating an indirect solar dryer for drying dairy products in Egypt. Bennamoun and Belhamri [29] numerically simulated the solar drying of seedless grapes in Algeria with the outlet temperature dominating the airflow rate. Simo-Tagne et al. [13] presented a numerical model and simulation of solar drying of red chili under the variable external condition of the African continent. Bala and Woods [30] presented a modelling of solar drying of rough rice, while Ayadi [31] considered the three major heat transfer modes in the simulation of solar drying of a medicinal plant in Tunisia with a good result. Other numerical simulations dealing with solar drying of hygroscopic products with good results have been presented also in literature [32-35].

All the numerical simulations reviewed above showed that the results obtained for each simulation is influenced by the thermophysical properties of the product, the design of the solar dryer and the external conditions of the validation environments, which depends on the seasonal variations. Moreover, literature dealing with the numerical simulation of solar drying of cassava roots is very scarce in the literature. Therefore, the objective of this research is to develop a numerical simulation model for solar drying of cassava roots in a convective mode based on heat and mass transfer, thermophysical properties, and the sorption isotherm of cassava roots. The model will be validated under the external variable condition of Cameroon and Ivory Coast, which are two major producers of cassava chips. The outcome will aid others in producing solar dryer designs and also help designers make informed decisions on design parameters.

\section{Materials and Methods}

\subsection{Description of the Solar Dryer}

The dryer was studied without and with the solar collector as presented in Figure 2, referred to as design 1 and design 2, respectively. The solar dryer presented in design 1 was experimentally validated in the Yamoussoukro region of Ivory Coast using cassava roots and was reported in the literature by Tieu et al. [36]. The dryer is an indirect passive solar dryer that is mostly common in Africa due to a lack of electricity [25]. The sides and the bottom faces are made with $10 \mathrm{~mm}$ thick plywood while the drying chamber is $1.773 \mathrm{~m}$ long, $0.313 \mathrm{~m}$ high (north side), and $0.86 \mathrm{~m}$ wide. Cassava roots chips are placed on a spread nylon sheet on top of the clay layer inside the drying chamber and arranged to form a rectangular shape that is $1.753 \mathrm{~m}$ long and $0.84 \mathrm{~m}$ wide. The air passes into the drying chamber through the inlet air section with dimensions of $0.6 \mathrm{~m} \times 0.04 \mathrm{~m}$. The hot and humid air rises by buoyancy and exits through a $1.5 \mathrm{~m}$ high chimney with a diameter of $50 \mathrm{~mm}$. The roof made up of blackened sheet metal is inclined at $10^{\circ}$ south to capture a lot of sunlight. Figure 2 shows design 2, which has a solar collector attached to form an indirect passive solar dryer. The collector has a dimension of $2 \mathrm{~m} \times 0.6 \mathrm{~m} \times 0.04 \mathrm{~m}$. The top of the solar collector is covered with a glass cover of $10 \mathrm{~mm}$ thickness. The absorber is made of a $1 \mathrm{~mm}$ thick steel plate painted black. Under the absorber is covered with a wooden panel that serves as thermal insulation. The dryer functions in natural convection, and therefore it is assumed that the air velocity in the solar collector, the drying chamber, and the chimney is close to the ambient air velocity given by the meteorological data of the town during the drying period. The typical weather condition of the Yaoundé environment 
used for the simulation is shown in Figure 3. Table 1 presents the physical properties of the experimental solar dryer used during the numerical simulations.

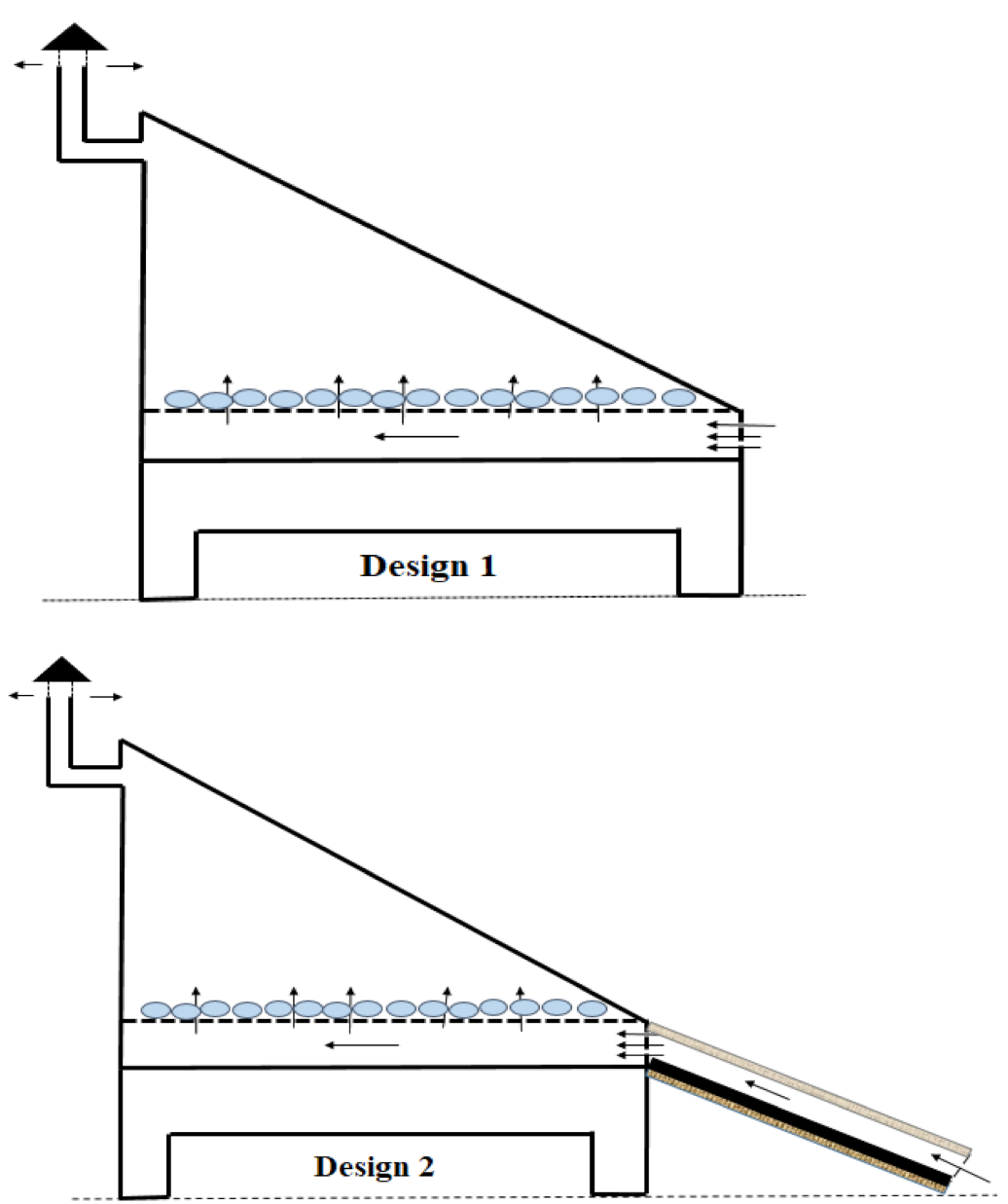

Figure 2. Schematic diagrams of the studied solar dryer without (design 1) and with (design2) a solar collector.

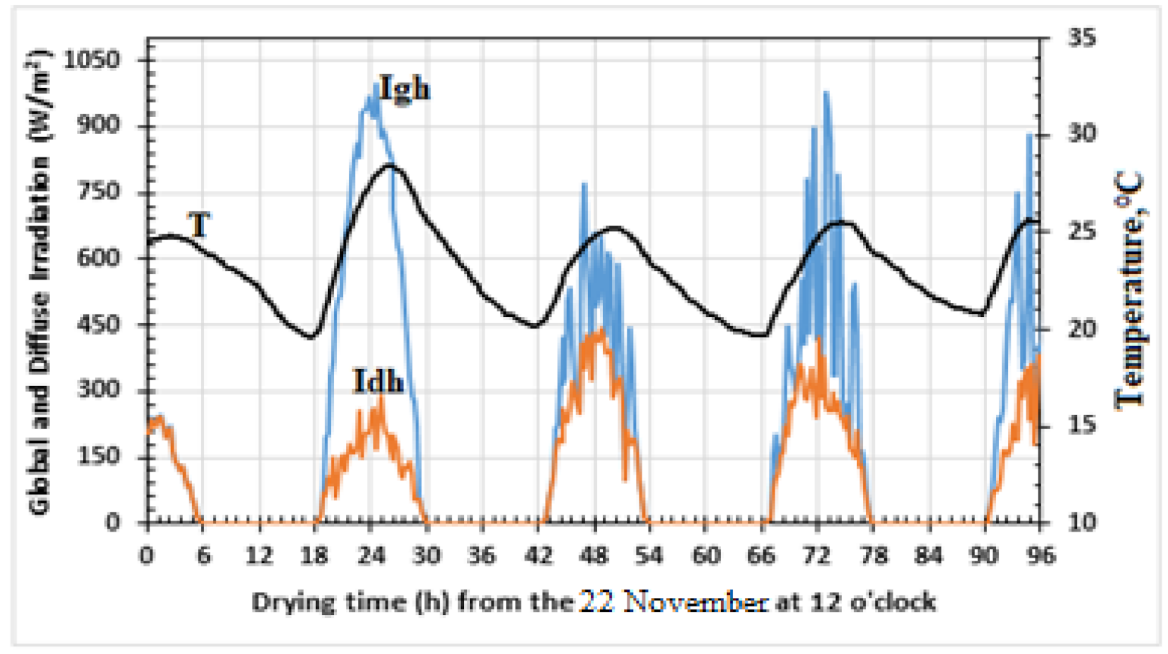

Figure 3. Ambient temperature as well as global and direct solar irradiation on a horizontal plane in Yaoundé from 22 November 2018 (taken from http:/ / www.meteonorm.com/). 


\subsection{Thermophysical Properties of Cassava Roots Used}

The sorption isotherm is very important in drying processes. It gives the equilibrium moisture content of the studied product at the given drying air relative humidity and temperature. The Guggenheim-Anderson-de Boer (GAB) model for equilibrium moisture content is highly recommended in the literature [37] because of its satisfactory results in all relative humidity ranges, allowing for a good approximation of the moisture content at the fiber saturation points. The performance of passive solar dryers is highly dependent on the constant periodic variations of the environmental conditions, and therefore it is important to have a continuous variation between the desorption isotherms and the drying air temperature as well as relative humidity. Thus, we used the GAB model to model the experimental data on desorption isotherms given by Ajala et al. [38]. The model obtained for the simulation is presented in Equation (1) with the parameters given in Table 2.

$$
\begin{gathered}
\mathrm{X}_{\mathrm{eq}}=\frac{\mathrm{X}_{\mathrm{m}} \cdot \mathrm{G} \cdot \mathrm{C} \cdot \mathrm{RH}}{(1-\mathrm{C} \cdot \mathrm{RH})(1+\mathrm{G} \cdot \mathrm{C} \cdot \mathrm{RH}-\mathrm{C} \cdot \mathrm{RH})} \\
\mathrm{X}_{\mathrm{m}}=\mathrm{X}_{\mathrm{mo}}+\mathrm{X}_{\mathrm{mo1}} \cdot \mathrm{T} \\
\mathrm{C}=\mathrm{C}_{\mathrm{o}} \exp \left(\frac{\Delta \mathrm{H}_{\mathrm{C}}}{\mathrm{R} \cdot \mathrm{T}}\right) \\
\mathrm{G}=\mathrm{G}_{\mathrm{o}} \exp \left(\frac{\Delta \mathrm{H}_{\mathrm{G}}}{\mathrm{R} \cdot \mathrm{T}}\right) \\
\mathrm{R}=8.314 \mathrm{~J} /(\mathrm{mol} \cdot \mathrm{K})
\end{gathered}
$$

Table 1. Physical properties and characteristics of the components of the solar dryer [13].

\begin{tabular}{cccc}
\hline Components & Areas $\left(\mathbf{m}^{2}\right)$ & Density $\left(\mathbf{k g} / \mathbf{m}^{3}\right)$ & Mass $(\mathbf{k g})$ \\
\hline \multicolumn{2}{c}{ Drying chamber } \\
\hline Roof & 1.550 & 2720 & 5.16 \\
\hline Wall & 0.824 & 450 & 3.709 \\
\hline Cassava roots chips & 1.473 & $840($ dry $)$ & $0.2386 \times \rho_{\mathrm{a}}$ \\
\hline Air drying & $0.2386\left(\right.$ volume in $\left.\mathrm{m}^{3}\right)$ & $\rho_{\mathrm{a}}=353 / \mathrm{T}_{\mathrm{a}}$ & \\
\hline \multicolumn{5}{c}{ Solar collector } \\
\hline Glass cover & 1.200 & 2530 & 5.36 \\
\hline Absorber & 1.200 & 2720 & 5.64 \\
\hline Wooden insulation & 1.200 & 450 & $0.0288 \times \rho_{\mathrm{f}}$ \\
\hline Airflow & $0.6 \times 0.04($ section $)$ & $\rho_{\mathrm{f}}=353 / \mathrm{T}_{\mathrm{f}}$ &
\end{tabular}

Table 2. Parameters desorption isotherms model of the GAB model obtained using data taken from Ajala et al. [38].

\begin{tabular}{cc}
\hline Parameters & Cassava Roots \\
\hline $\mathrm{X}_{\mathrm{mo}}(\mathrm{kg} / \mathrm{kg})$ & 0.20444366 \\
\hline $\mathrm{X}_{\mathrm{mo} 1}(\mathrm{~kg} /(\mathrm{kg} \cdot \mathrm{K}))$ & -0.00034997 \\
\hline $\mathrm{C}_{\mathrm{o}}(-)$ & 0.1809885 \\
\hline$\left.\Delta \mathrm{H}_{\mathrm{C}} \mathrm{J} / \mathrm{mol}\right)$ & 1917.2676 \\
\hline $\mathrm{G}_{\mathrm{o}}(-)$ & 6632.002 \\
\hline$\Delta \mathrm{H}_{\mathrm{G}}(\mathrm{J} / \mathrm{mol})$ & $-11,219.687$ \\
\hline
\end{tabular}


From Figure 4, the moisture contents in the first layer were not influenced by the air-drying temperature when the equilibrium moisture content of the product is lower than $0.075 \mathrm{~kg} / \mathrm{kg}$. For the equilibrium moisture contents above 0.075 , when the drying air temperature increases, the moisture contents at the first layer decrease. A great difference in energies needed to extract one mole of bound water in the studied products $\left(\Delta \mathrm{H}_{\mathrm{C}}\right.$ and $\Delta \mathrm{H}_{\mathrm{G}}$ ) is observed. When drying air temperature increases, equilibrium moisture contents decrease showing that the increase of temperature is favorable for the extraction of the bound water in the studied products. The desorption isotherms increase when the air relative humidity increases. When the temperature increases, the influence of the air relative humidity on the desorption isotherms of the products decreases.

Figure 4 presents some desorption isotherm curves of cassava roots. We can see a good agreement between the experimental points and the numerical curves, showing that the GAB model gave a satisfactory result. To obtain all GAB's parameters, all the squares of the regression coefficients were higher than $0.8\left(r^{2}>0.8\right)$.

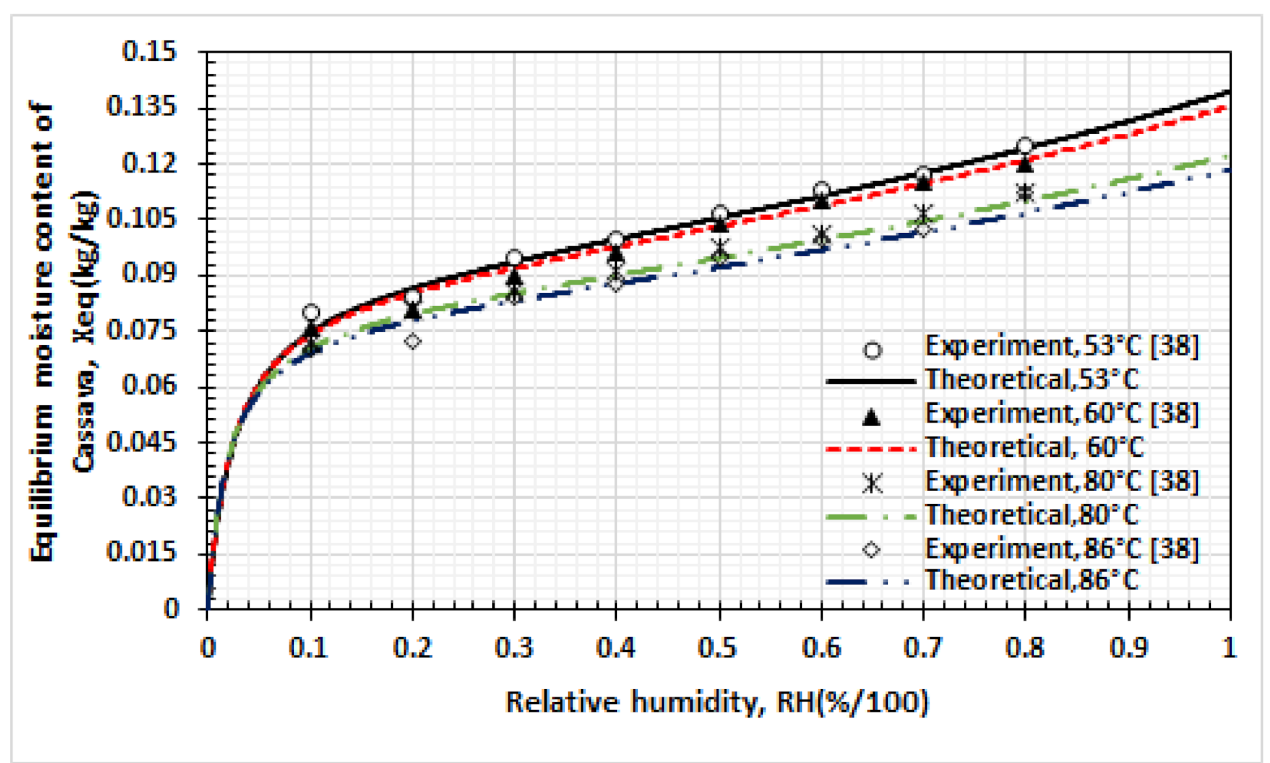

Figure 4. Validation of four curves of desorption isotherms of cassava roots using the parameters of Table 2 at temperatures of $53,60,80$, and $86^{\circ} \mathrm{C}$.

To obtain the specific heat and thermal conductivity of cassava roots, we used the relationships recommended for agriculture products [13]:

$$
\begin{gathered}
\mathrm{C}_{\text {pcas }}=837+3348\left(\frac{\mathrm{H}}{1+\mathrm{H}}\right) \\
\lambda_{\text {cas }}=0.49-0.44 \exp (-0.206 \mathrm{H})
\end{gathered}
$$

The average density of cassava roots is taken as $\rho_{\text {cas }}=840 \mathrm{~kg} / \mathrm{m}^{3}$. In effect, Baharuddin et al. [39] obtained this value in the range of 810 to $870 \mathrm{~kg} / \mathrm{m}^{3}$ according to the maturity age of the cassava roots. The value of dry density used is given by Baharuddin et al. [39] as $670 \mathrm{~kg} / \mathrm{m}^{3}$. Fernando et al. [40] found that the moisture diffusion coefficient of cassava roots is located between $1.18 \times 10^{-9}$ to $6.16 \times 10^{-9} \mathrm{~m}^{2} / \mathrm{s}$. In this study, we used an Arrhenius variation of the mass diffusion coefficient such as the one used by Ajala et al. [41]:

$$
\mathrm{D}_{\text {Hcas }}=\mathrm{D}_{\mathrm{o}} \exp \left(-\frac{\mathrm{E}_{\mathrm{a}}}{\mathrm{RT}_{\mathrm{a}}}\right)
$$

When applied on Cassava, Ajala et al. [41] found activation energy of $E_{a}=30,300 \mathrm{~J} / \mathrm{mol}$. This value of activation energy is used for the simulation. The mass diffusivity constant 
used during the simulation of the drying of pretreated okra by Kuitche et al. [42] was $D_{0}=1.8 \times 10^{-5} \mathrm{~m}^{2} / \mathrm{s}$. In this work, we used $D_{0}=3.25 \times 10^{-4} \mathrm{~m}^{2} / \mathrm{s}$ in the range of acceptable values obtained on agro-products [42].

The thermal diffusivity is given by:

$$
\mathrm{D}_{\text {Tcas }}=\frac{\lambda_{\text {cas }}}{\rho_{\text {cas }} C_{\text {pcas }}}
$$

\subsection{Heat Mass Transfer on the Products}

The heat transfer by radiation between the products and the walls, roof, and the floor of the drying chamber was neglected by studies such as the one by Simo-Tagne et al. [35]. We assume that the tray does not influence heat mass transfer.

\subsubsection{Roots of Cassava}

We assume that the product has a thin layer configuration. Only the transfers in the thickness orientation are taken into account. Then, we have the following in the product:

$$
\begin{aligned}
\frac{\partial \mathrm{T}}{\partial \mathrm{t}} & =\mathrm{D}_{\mathrm{Tcas}} \frac{\partial^{2} \mathrm{~T}}{\partial \mathrm{x}^{2}} \\
\frac{\partial \mathrm{H}}{\partial \mathrm{t}} & =\mathrm{D}_{\mathrm{Hcas}} \frac{\partial^{2} \mathrm{H}}{\partial \mathrm{x}^{2}}
\end{aligned}
$$

We also assume that during the drying process, the contact between the clay and the inlet air is considered perfect. Thus, when the solar collector is used (design 2), we have the following:

$$
\begin{gathered}
\mathrm{T}(\mathrm{x}=0)=\mathrm{T}_{\mathrm{f}}\left(\mathrm{z}=\mathrm{z}_{\max }\right) \\
\mathrm{H}(\mathrm{x}=0)=\mathrm{X}_{\mathrm{eq}}\left(\mathrm{T}_{\mathrm{fs}}\left(\mathrm{z}=\mathrm{z}_{\max }\right) ; \mathrm{RH}_{\mathrm{fs}}\left(\mathrm{z}=\mathrm{z}_{\max }\right)\right)
\end{gathered}
$$

when the solar collector is not used (design 1), we have:

$$
\begin{gathered}
\mathrm{T}(\mathrm{x}=0)=\mathrm{T}_{\mathrm{aE}} \\
\mathrm{H}(\mathrm{x}=0)=\mathrm{X}_{\mathrm{eq}}\left(\mathrm{T}_{\mathrm{aE}} ; \mathrm{RH}_{\mathrm{aE}}\right)
\end{gathered}
$$

At the surface of the product, we have:

$$
\begin{gathered}
-\left.\lambda_{\text {cas }} \frac{\partial \mathrm{T}}{\partial \mathrm{x}}\right|_{\mathrm{x}=\mathrm{ep}}=\mathrm{h}_{\mathrm{c}}\left(\mathrm{T}_{\mathrm{x}=\mathrm{ep}}-\mathrm{T}_{\mathrm{a}}\right) \\
-\left.\mathrm{D}_{\text {Hcas }} \frac{\partial \mathrm{H}}{\partial \mathrm{x}}\right|_{\mathrm{x}=\mathrm{ep}}=\mathrm{h}_{\mathrm{m}}\left(\mathrm{H}_{\mathrm{x}=\mathrm{ep}}-\mathrm{X}_{\mathrm{eq}}\right)
\end{gathered}
$$

\subsubsection{Drying Chamber}

We assume that the temporal variation of the sensible energy of each component of the solar dryer is equal to the sum of all power energy exchanged between the component and all other parts of the dryer. Thus, we have the following:

For the roof:

$$
\mathrm{m}_{\mathrm{r}} \mathrm{C}_{\mathrm{pr}} \frac{\partial \mathrm{T}_{\mathrm{r}}}{\partial \mathrm{t}}=\mathrm{A}_{\mathrm{r}} \mathrm{h}_{\text {cext }}\left(\mathrm{T}_{\text {ext }}-\mathrm{T}_{\mathrm{r}}\right)+\mathrm{A}_{\mathrm{r}} \mathrm{F}_{\mathrm{r}-\mathrm{sk}}\left(\mathrm{T}_{\mathrm{sk}}^{4}-\mathrm{T}_{\mathrm{r}}^{4}\right)+\mathrm{A}_{\mathrm{r}} \mathrm{h}_{\text {cint }}\left(\mathrm{T}_{\mathrm{a}}-\mathrm{T}_{\mathrm{r}}\right)+\alpha_{\mathrm{r}} \mathrm{A}_{\mathrm{r}} \mathrm{I}_{\mathrm{G}}
$$

The walls:

$$
\mathrm{m}_{\mathrm{w}} \mathrm{C}_{\mathrm{pw}} \frac{\partial \mathrm{T}_{\mathrm{w}}}{\partial \mathrm{t}}=\mathrm{A}_{\mathrm{w}} \mathrm{h}_{\mathrm{cext}}\left(\mathrm{T}_{\mathrm{ext}}-\mathrm{T}_{\mathrm{w}}\right)+\mathrm{A}_{\mathrm{w}} \mathrm{h}_{\text {cint }}\left(\mathrm{T}_{\mathrm{a}}-\mathrm{T}_{\mathrm{w}}\right)+\alpha_{\mathrm{w}} \mathrm{A}_{\mathrm{w}} \mathrm{I}_{\mathrm{G}}
$$


Drying air:

$\mathrm{m}_{\mathrm{a}} \mathrm{C}_{\mathrm{pa}} \frac{\partial \mathrm{T}_{\mathrm{a}}}{\partial \mathrm{t}}=\mathrm{A}_{\mathrm{w}} \mathrm{h}_{\text {cint }}\left(\mathrm{T}_{\mathrm{w}}-\mathrm{T}_{\mathrm{a}}\right)+\mathrm{A}_{\mathrm{r}} \mathrm{h}_{\mathrm{cint}}\left(\mathrm{T}_{\mathrm{r}}-\mathrm{T}_{\mathrm{a}}\right)+\mathrm{A}_{\mathrm{p}} \mathrm{h}_{\mathrm{cp}}\left(\mathrm{T}-\mathrm{T}_{\mathrm{a}}\right)+\dot{m} \mathrm{C}_{\mathrm{pa}}\left(\mathrm{T}_{\mathrm{fs}}-\mathrm{T}_{\mathrm{a}}\right)+\dot{m} \mathrm{C}_{\mathrm{pv}}\left(\mathrm{Y}_{\mathrm{E}} \mathrm{T}_{\mathrm{fs}}-\mathrm{Y}_{\mathrm{s}} \mathrm{T}_{\mathrm{a}}\right)$

$$
\mathrm{m}_{\mathrm{a}} \frac{\partial \mathrm{Y}_{\mathrm{s}}}{\partial \mathrm{t}}=\dot{m}\left(\mathrm{Y}_{\mathrm{E}}-\mathrm{Y}_{\mathrm{s}}\right)-\mathrm{m}_{0} \frac{\partial \mathrm{H}}{\partial \mathrm{t}}
$$

The dry mass of the product used during the experiment is equal to $\mathrm{m}_{0}=14.804 \mathrm{~kg}$.

$$
\mathrm{P}_{\mathrm{v}}=\text { RH.P } \mathrm{P}_{\mathrm{vsat}}\left(\mathrm{T}_{\mathrm{a}}\right)
$$

The drying kinetics is given by the expression $\frac{\partial \mathrm{H}}{\partial \mathrm{t}}$.

We also assume that the humidity of the inlet and outlet air is the same in the solar collector. Thus the relative humidity of outlet air $\left(\mathrm{RH}_{\mathrm{fs}}\right)$ is given by:

$$
\mathrm{RH}_{\mathrm{fs}}=\frac{\mathrm{P}_{\mathrm{vsatE}}}{\mathrm{P}_{\mathrm{vsatfs}}} \mathrm{RH}_{\mathrm{E}}
$$

$\mathrm{RH}_{\mathrm{E}}$ is the relative humidity of ambient air; and $\mathrm{P}_{\mathrm{vsatE}}$ and $\mathrm{P}_{\mathrm{vsatfs}}$ are the pressure of vapor at the saturation state of the ambient air and the outlet the solar collector, respectively.

\subsubsection{Solar Collector}

Glass Cover in Solar Collector

Using the same assumptions taken at the level of drying chamber, we have the following:

$$
\frac{\mathrm{m}_{\mathrm{g}} \mathrm{C}_{\mathrm{pg}}}{\mathrm{A}_{\mathrm{g}}} \frac{\partial \mathrm{T}_{\mathrm{gc}}}{\partial \mathrm{t}}=\alpha_{\mathrm{gc}}\left(1+\tau_{\mathrm{gc}} \rho_{p}\right) \mathrm{I}_{\mathrm{G}}+\mathrm{h}_{\mathrm{rpg}}\left(\mathrm{T}_{\mathrm{pc}}-\mathrm{T}_{\mathrm{gc}}\right)+\mathrm{h}_{\mathrm{cgf}}\left(\mathrm{T}_{\mathrm{f}}-\mathrm{T}_{\mathrm{gc}}\right)+\mathrm{h}_{\mathrm{cext}}\left(\mathrm{T}_{\mathrm{aE}}-\mathrm{T}_{\mathrm{gc}}\right)+\mathrm{h}_{\mathrm{rgc}}\left(\mathrm{T}_{\mathrm{sky}}-\mathrm{T}_{\mathrm{gc}}\right)
$$

Both $\mathrm{h}_{\mathrm{rpg}}$ and $\mathrm{h}_{\mathrm{rgc}}$ are taken from Simo-Tagne et al. [43] and given by:

$$
\begin{gathered}
\mathrm{h}_{\mathrm{rpg}}=\frac{\sigma\left(\mathrm{T}_{\mathrm{pc}}^{2}+\mathrm{T}_{\mathrm{gc}}^{2}\right)\left(\mathrm{T}_{\mathrm{pc}}+\mathrm{T}_{\mathrm{gc}}\right)}{\frac{1}{\epsilon_{\mathrm{p}}}+\frac{1}{\epsilon_{\mathrm{g}}}-1} \\
\mathrm{~h}_{\mathrm{rgc}}=\epsilon_{\mathrm{g}} \sigma\left(\mathrm{T}_{\mathrm{sky}}^{2}+\mathrm{T}_{\mathrm{gc}}^{2}\right)\left(\mathrm{T}_{\text {sky }}+\mathrm{T}_{\mathrm{gc}}\right)
\end{gathered}
$$

where $\epsilon_{\mathrm{p}}=0.11, \epsilon_{\mathrm{g}}=0.89$ and $\rho_{p}=0.06$ [13].

The absorber with insulation plate in solar collector is calculated as follows:

$$
\frac{\mathrm{m}_{\mathrm{p}} \mathrm{C}_{\mathrm{pc}}}{\mathrm{A}_{\mathrm{pc}}} \frac{\partial \mathrm{T}_{\mathrm{pc}}}{\partial \mathrm{t}}=\frac{\alpha_{\mathrm{p}} \tau_{\mathrm{gc}} \mathrm{I}_{\mathrm{G}}}{1-\rho_{\mathrm{p}} \rho_{\mathrm{gc}}}+\mathrm{U}_{\mathrm{b}}\left(\mathrm{T}_{\mathrm{aE}}-\mathrm{T}_{\mathrm{pc}}\right)+\mathrm{h}_{\mathrm{cpf}}\left(\mathrm{T}_{\mathrm{f}}-\mathrm{T}_{\mathrm{pc}}\right)+\mathrm{h}_{\mathrm{rpg}}\left(\mathrm{T}_{\mathrm{gc}}-\mathrm{T}_{\mathrm{pc}}\right)
$$

where $\rho_{\mathrm{gc}}=\rho_{p}=0.06[13]$.

$$
\mathrm{U}_{\mathrm{b}}=\frac{1}{\frac{1}{\mathrm{~h}_{\mathrm{cext}}}+\frac{\mathrm{e}_{\mathrm{b}}}{\lambda_{\mathrm{b}}}+\frac{\mathrm{e}_{\mathrm{pc}}}{\lambda_{\mathrm{pc}}}+\frac{1}{\mathrm{~h}_{\mathrm{cpf}}+\mathrm{h}_{\mathrm{rpg}}}}
$$

The airflow between absorber plate and glass cover in solar collector is as follows:

$$
\frac{\mathrm{m}_{\mathrm{f}} \mathrm{C}_{\mathrm{pf}}}{\mathrm{A}_{\mathrm{f}}} \frac{\partial \mathrm{T}_{\mathrm{f}}}{\partial \mathrm{t}}+\frac{\dot{\mathrm{m}} \mathrm{C}_{\mathrm{pf}}}{\mathrm{l}_{\mathrm{c}}} \frac{\partial \mathrm{T}_{\mathrm{f}}}{\partial \mathrm{z}}=\mathrm{h}_{\mathrm{cpf}}\left(\mathrm{T}_{\mathrm{pc}}-\mathrm{T}_{\mathrm{f}}\right)+\mathrm{h}_{\mathrm{cgf}}\left(\mathrm{T}_{\mathrm{gc}}-\mathrm{T}_{\mathrm{f}}\right)
$$




\subsubsection{Heat and Mass Transfer Coefficients}

In the drying chamber, the convective heat transfer coefficients between a solid surface and the air inside are given by Churchill and $\mathrm{Chu}$ and taken from Incropera et al. [44]. We have the following:

$$
\begin{aligned}
& \mathrm{h}_{\mathrm{c}}=\frac{\mathrm{Nu} \cdot \lambda_{\mathrm{a}}}{\mathrm{d}_{\mathrm{H}}} \\
& \mathrm{h}_{\mathrm{m}}=\frac{\text { Sh.D } \mathrm{D}_{\mathrm{a}}}{\mathrm{d}_{\mathrm{H}}}
\end{aligned}
$$

The hydraulic diameter is given by:

$$
\mathrm{d}_{\mathrm{H}}=\frac{4 \mathrm{Vol}_{\mathrm{a}}}{\operatorname{Sur}_{\mathrm{a}}}=0.2481 \mathrm{~m}
$$

$\mathrm{Vol}_{\mathrm{a}}$ and $\mathrm{Sur}_{\mathrm{a}}$ are respectively the volume and surface of the drying chamber.

The Nusselt number and the Sherwood number were used to obtain the convective heat transfer coefficient and the convective mass transfer coefficient between air drying and cassava, respectively. The Nusselt number was taken from Incropera et al. [44] as follows:

$$
\mathrm{Nu}_{\text {Air-Cass }}=0.54 \mathrm{Ra}^{1 / 4}
$$

Bower and Saylor [45] gave the Sherwood number as:

$$
\begin{gathered}
\mathrm{Sh}_{\text {Air-Cass }}=0.23 \mathrm{Sc}^{1 / 3} \mathrm{Ra}^{0.321} \\
\mathrm{Ra}=\text { Gr.Pr }
\end{gathered}
$$

With:

$$
\begin{aligned}
\mathrm{Sc} & =\frac{v_{\mathrm{a}}}{\mathrm{D}_{\mathrm{a}}} \\
v_{\mathrm{a}} & =\frac{\mu_{\mathrm{a}}}{\rho_{\mathrm{a}}}
\end{aligned}
$$

The Nusselt number was used to obtain the convective heat transfer coefficient between the wall and the air inside the drying chamber; it is given by Churchill and Chu and was taken from Incropera et al. [44]:

$$
\mathrm{Nu}_{\mathrm{pLa}}=\left[0.825+\frac{0.387 \mathrm{Ra}_{\mathrm{L}}^{1 / 6}}{\left[1+(0.492 / \mathrm{Pr})^{9 / 16}\right]^{8 / 27}}\right]^{2}
$$

The Nusselt number for the convective heat transfer coefficient between the roof and the air inside the drying chamber is also given by Churchill and Chu and taken from Incropera et al. [44] as follows:

$$
\mathrm{Nu}_{\mathrm{ia}}=\frac{0.677 \mathrm{Pr}^{1 / 2} \mathrm{Gr}^{1 / 4}}{[0.95+\operatorname{Pr}]^{1 / 4}}
$$

To obtain the Grashof number (Gr), the intensity of gravity $g$ was changed to gcos $\alpha$, where $\alpha$ is the angle between the roof and the vertical height $\left(80^{\circ}\right.$ in this case).

To obtain the convective heat transfer coefficients in the solar collector due to the natural convection between the airflow and the glass cover $\left(\mathrm{h}_{\mathrm{cgf}}\right)$ as well as that between the airflow and the absorber $\left(\mathrm{h}_{\mathrm{cpf}}\right)$, the Nusselt number was obtained from Simo-Tagne et al. [43]:

$$
\mathrm{N}_{\mathrm{uCol}}=1+1.44\left[\frac{\left|1-\frac{1708}{\mathrm{R}_{\mathrm{a}} \cos \alpha}\right|+1-\frac{1708}{\mathrm{R}_{\mathrm{a}} \cos \alpha}}{2}\right]\left[1-\frac{1708(\sin (1.8 \alpha))^{1.8}}{\mathrm{R}_{\mathrm{a}} \cos \alpha}\right]+\frac{\left|\left(\frac{\mathrm{R}_{\mathrm{a}} \cos \alpha}{5830}\right)^{1 / 3}-1\right|+\left(\frac{\mathrm{R}_{\mathrm{a}} \cos \alpha}{5830}\right)^{1 / 3}-1}{2}
$$


where $\alpha$ is the angle between the solar collector and the horizontal plane $\left(10^{\circ}\right)$, Ra number was obtained at the average temperature of the airflow and the solid surface.

\subsection{Method of Resolution}

To resolve Equations (6a)-(6h), the finite differences method was used because it is highly recommended for its stability. Thus, we have the following for Equation $(6 a, b)$ :

$$
\begin{aligned}
& \left\{\begin{array}{c}
\mathrm{T}_{\mathrm{i}}^{\mathrm{j}+1}=\mathrm{C}_{1 \mathrm{~T}_{\mathrm{i}}^{\mathrm{j}}}^{\mathrm{j}} \mathrm{T}_{\mathrm{i}}^{\mathrm{j}}+\mathrm{C}_{2 \mathrm{~T}_{\mathrm{i}}^{\mathrm{j}}}^{\mathrm{j}}\left(\mathrm{T}_{\mathrm{i}+1}^{\mathrm{j}}+\mathrm{T}_{\mathrm{i}-1}^{\mathrm{j}}\right) \\
\mathrm{H}_{\mathrm{i}}^{\mathrm{j}+1}=\mathrm{C}_{1} \mathrm{H}_{\mathrm{i}}^{\mathrm{j}} \mathrm{H}_{\mathrm{i}}^{\mathrm{j}}+\mathrm{C}_{2 \mathrm{H}_{\mathrm{i}}^{\mathrm{j}}}\left(\mathrm{H}_{\mathrm{i}+1}^{\mathrm{j}}+\mathrm{H}_{\mathrm{i}-1}^{\mathrm{j}}\right)
\end{array}\right. \\
& \mathrm{C}_{1 \mathrm{~T}_{\mathrm{i}}^{\mathrm{j}}}^{\mathrm{j}}=1-\left.\frac{2 \mathrm{D}_{\text {Tcas }} \Delta \mathrm{t}}{(\Delta \mathrm{x})^{2}}\right|_{\mathrm{i}} ^{\mathrm{j}} \\
& C_{2 T_{i}^{j}}^{j}=\left.\frac{D_{\text {Tcas }} \Delta t}{(\Delta x)^{2}}\right|_{i} ^{j} \\
& \mathrm{C}_{1 \mathrm{H}_{\mathrm{i}}}{ }^{\mathrm{j}}=1-\left.\frac{2 \mathrm{D}_{\mathrm{Hcas}} \Delta \mathrm{t}}{(\Delta \mathrm{x})^{2}}\right|_{\mathrm{i}} ^{\mathrm{j}} \\
& \mathrm{C}_{2 \mathrm{H}_{\mathrm{i}}^{\mathrm{j}}}=\left.\frac{\mathrm{D}_{\mathrm{Hcas}} \Delta \mathrm{t}}{(\Delta \mathrm{x})^{2}}\right|_{\mathrm{i}} ^{\mathrm{j}}
\end{aligned}
$$

Equations (6c) and (6d) give the following:

$$
\begin{gathered}
\mathrm{T}_{0}^{\mathrm{j}}=\mathrm{T}_{\mathrm{f}}^{\mathrm{j}}\left(\mathrm{z}=\mathrm{z}_{\max }\right) \\
\mathrm{H}_{0}^{\mathrm{j}}=\mathrm{X}_{\mathrm{eq}}\left(\mathrm{T}_{\mathrm{f}}^{\mathrm{j}}\left(\mathrm{z}=\mathrm{z}_{\max }\right) ; \mathrm{RH}_{\mathrm{f}}^{\mathrm{j}}\left(\mathrm{z}=\mathrm{z}_{\max }\right)\right)
\end{gathered}
$$

Equations (6e) and (6f) give the following:

$$
\begin{gathered}
\mathrm{T}_{0}^{\mathrm{j}}=\mathrm{T}_{\mathrm{aE}}^{\mathrm{j}} \\
\mathrm{H}_{0}^{\mathrm{j}}=\mathrm{X}_{\mathrm{eq}}\left(\mathrm{T}_{\mathrm{aE}}^{\mathrm{j}} ; \mathrm{RH}_{\mathrm{aE}}^{\mathrm{j}}\right)
\end{gathered}
$$

Equations (6g) and (6h) give respectively the following:

$$
\begin{gathered}
\mathrm{T}_{\mathrm{N}+1}^{\mathrm{j}}=\left.\left(1-\frac{\mathrm{h}_{\mathrm{c}} \Delta \mathrm{x}}{\lambda_{\text {cas }}}\right)\right|_{\mathrm{N}+1} ^{\mathrm{j}} \mathrm{T}_{\mathrm{N}}^{\mathrm{j}}+\left.\frac{\mathrm{h}_{\mathrm{c}} \Delta \mathrm{x}}{\lambda_{\text {cas }}}\right|_{\mathrm{N}+1} ^{\mathrm{j}} \mathrm{T}_{\mathrm{a}}^{\mathrm{j}} \\
\mathrm{H}_{\mathrm{N}+1}^{\mathrm{j}}=\left.\left(1-\frac{\mathrm{h}_{\mathrm{m}} \Delta \mathrm{x}}{\mathrm{D}_{\text {Hcas }}}\right)\right|_{\mathrm{N}+1} ^{\mathrm{j}} \mathrm{H}_{\mathrm{N}}^{\mathrm{j}}+\left.\frac{\mathrm{h}_{\mathrm{m}} \Delta \mathrm{x}}{\mathrm{D}_{\text {Hcas }}}\right|_{\mathrm{N}+1} ^{\mathrm{j}} \mathrm{X}_{\mathrm{eq}}\left(\mathrm{T}_{\mathrm{a}}^{\mathrm{j}} ; \mathrm{RH}_{\mathrm{a}}^{\mathrm{j}}\right)
\end{gathered}
$$

To resolve Equations (7), (8), (9a), (9b), (10a) and (10d), we used the 4th order RungeKutta method. This method has been used with great satisfaction in literature when the partial differential equation is the only function of drying time by Simo-Tagne et al. [43]. To resolve Equation (11), we used the same assumption as Njomo [46] where the sensible heat is neglected. Thus, we have the following:

$$
\frac{\dot{\mathrm{m}} \mathrm{C}_{\mathrm{pf}}}{\mathrm{l}_{\mathrm{c}}} \frac{\partial \mathrm{T}_{\mathrm{f}}}{\partial \mathrm{z}}=\mathrm{h}_{\mathrm{cpf}}\left(\mathrm{T}_{\mathrm{pc}}-\mathrm{T}_{\mathrm{f}}\right)+\mathrm{h}_{\mathrm{cgf}}\left(\mathrm{T}_{\mathrm{gc}}-\mathrm{T}_{\mathrm{f}}\right)
$$

With:

$$
\mathrm{T}_{\mathrm{f}}(\mathrm{z}=0)=\mathrm{T}_{\mathrm{aE}}
$$


Along with the solar collector, the heater of the fresh air coming from ambient is given by the analytical solution:

$$
\mathrm{T}_{\mathrm{f}}(\mathrm{z})=\frac{\mathrm{h}_{\mathrm{cpf}} \mathrm{T}_{\mathrm{pc}}+\mathrm{h}_{\mathrm{cgf}} \mathrm{T}_{\mathrm{gc}}}{\mathrm{h}_{\mathrm{cpf}}+\mathrm{h}_{\mathrm{cgf}}}+\left(\mathrm{T}_{\mathrm{aE}}-\frac{\mathrm{h}_{\mathrm{cpf}} \mathrm{T}_{\mathrm{pc}}+\mathrm{h}_{\mathrm{cgf}} \mathrm{T}_{\mathrm{gc}}}{\mathrm{h}_{\mathrm{cpf}}+\mathrm{h}_{\mathrm{cgf}}}\right) \exp \left(-\frac{\left(\mathrm{h}_{\mathrm{cpf}}+\mathrm{h}_{\mathrm{cgf}}\right) \mathrm{z}}{\rho_{\mathrm{f}} \mathrm{e}_{\mathrm{sc}} \mathrm{V}_{\mathrm{aE}} \mathrm{C}_{\mathrm{pf}}}\right)
$$

With:

$$
\dot{\mathrm{m}}=\rho_{\mathrm{f}} \mathrm{e}_{\mathrm{sc}} \mathrm{l}_{\mathrm{c}} \mathrm{V}_{\mathrm{aE}}
$$

According to the experimental solar dryer [36], the width $\left(l_{c}\right)$ and thickness $\left(e_{s c}\right)$ of the airflow in the solar collector were equal to $0.6 \mathrm{~m}$ and $0.04 \mathrm{~m}$, respectively. Table 3 presents the thermal properties of the solar dryer used during the numerical simulations. The thermophysical parameters of the drying air used are presented in Appendix A. Prandtl and Grashop numbers are showed in Appendix B. The time step was equal to $1 \mathrm{~s}$, but the results were recorded each $1 \mathrm{~h}$ of drying time. The $2 \mathrm{~m}$ length of the solar collector was divided into 250 parts, and the $15 \mathrm{~mm}$ thickness of each sample of cassava was divided into 50 parts. We used the Fortran 90 language to have all numerical data.

\begin{tabular}{|c|c|c|c|c|}
\hline Components & $\begin{array}{c}\text { Specific Heat Capacity } \\
(\mathrm{J} /(\mathrm{kg} \cdot \mathrm{K}))\end{array}$ & $\begin{array}{l}\text { Thermal Conductivity } \\
(\mathrm{W} /(\mathrm{m} . \mathrm{K}))\end{array}$ & $\begin{array}{l}\text { Absorptivity } \\
\text { Coefficient (-) }\end{array}$ & $\begin{array}{l}\text { Transmitivity } \\
\text { Coefficient (-) }\end{array}$ \\
\hline \multicolumn{5}{|c|}{ For the drying chamber } \\
\hline Roof & 900 & 190 & 0.91 & 0 \\
\hline Wall & 1600 & 0.13 & 0.4 & 0 \\
\hline Cassava roots chips & See Equation (2) & See Equation (3) & $(-)$ & $(-)$ \\
\hline Air drying & See Equations (A2) and (A3) & See Equation (A1) & $(-)$ & $(-)$ \\
\hline \multicolumn{5}{|c|}{ For the solar collector } \\
\hline Glass cover & 800 & 0.1311 & 0.1 & 0.89 \\
\hline Absorber & 900 & 190 & 0.91 & 0 \\
\hline Wooden insulation & 1236 & 0.14 & $(-)$ & $(-)$ \\
\hline Airflow & See Equations (A2) and (A3) & See Equation (A1) & 0.1 & 0.9 \\
\hline
\end{tabular}

Table 3. Thermal properties of the components of solar dryer [43,47].

\section{Results and Discussion}

\subsection{Model Validation in Yamoussoukro (Ivory Coast)}

Figure 5 was obtained using the experimental data of Tieu et al. [36] with the solar dryer in design 1, in the town of Yamoussoukro in Ivory Coast from 18 October 2018 to 20 October 2018. All meteorological data for the days of the experiments were presented in the literature [48] and were integrated into the model. The model gave a satisfactory result between the experimental and theoretical results with the difference between experimental data and numerical data of moisture content on a dry basis with less than $0.2 \mathrm{~kg} / \mathrm{kg}$ (dry basis) moisture content difference. Figure 6 shows that the design influenced the drying kinetic of the product. When the solar collector is used in design 2, the drying air temperature is more heated and increases the mass diffusion coefficients, thus increasing the drying rate. Therefore, the drying curve becomes steeper compared to design 1 . However, this variation was not too high because during the night and less sunny days, the solar collector does not have a satisfactory influence. This is the reason that supplementary heat is advocated in most West African states [14].

Figure 7 presents the evolution of the temperatures within the solar drying system in comparison with the ambient temperature. During the day, the exit air from the collector changes the temperature of the drying air in the drying chamber, thereby raising its value. During the night, the temperature of the air in the drying chamber decreases to the ambient 
air temperature values. This is the major reason the air inlet is closed during the offsunshine period in order to stop the renewal of the air in the drying chamber as well as to insulate the walls, roof, and floor of the drying chamber to decrease energy loss by conduction or convection.

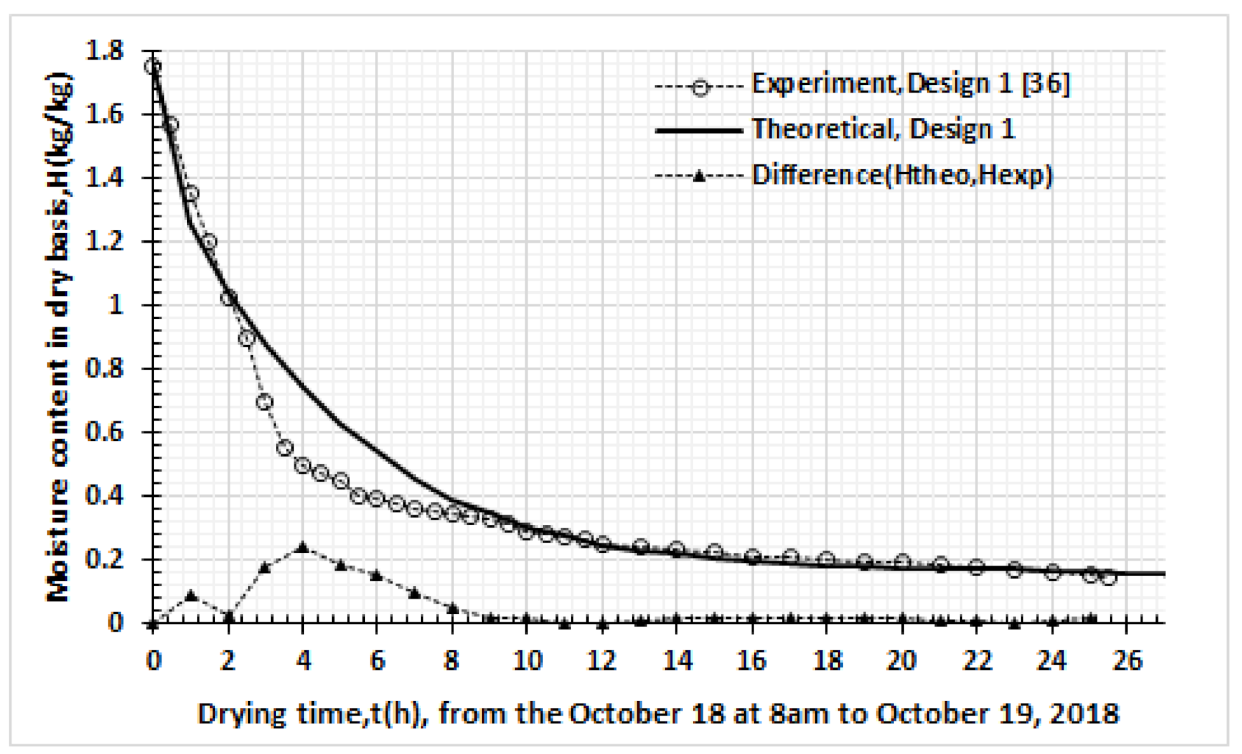

Figure 5. Validation of the model using experimental data given by Tieu et al. [36] in Yamoussoukro, October 2018, design 1.

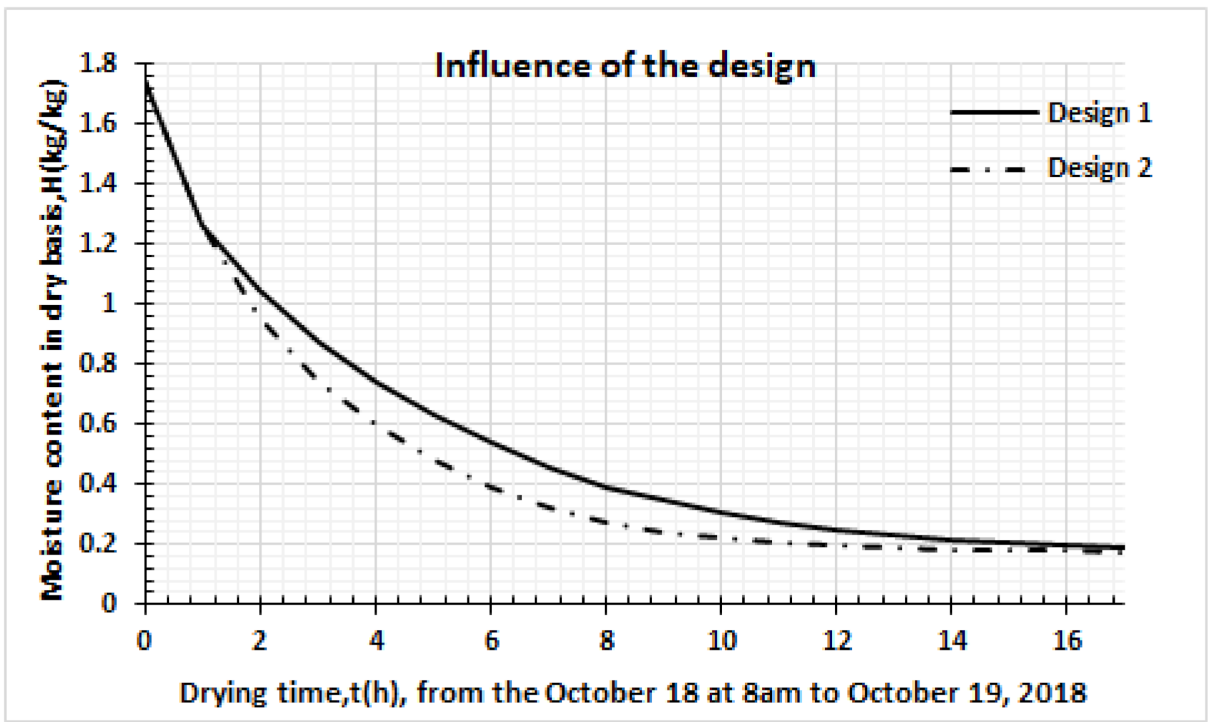

Figure 6. Influence of the design on the drying kinetic in Yamoussoukro, October 2018, designs 1 and 2.

\subsection{Heat Mass Transfer Coefficients, Heat Mass Gradients and Drying Kinetic in Yaoundé (Cameroon)}

Figure 8 shows the convective heat and mass transfer coefficients, the temperature of cassava, the relative humidity of drying air, and the moisture content evolutions during the drying of cassava in Yaoundé from 18 November 2018. The meteorological data of the drying periods were presented previously in Figure 3. Figure 8a shows that the heat transfer (about $25 \mathrm{~W} / \mathrm{m}^{2} \mathrm{~s}$ ) is by convection between the airflow and absorber, and between the airflow and glass cover during the sunny periods. The maximum values of the heat transfer coefficients between the drying air and the product and the walls are about $4 \mathrm{~W} / \mathrm{m}^{2} \mathrm{~s}$. 
The global heat transfer coefficient below the solar collector $U_{b}$ varied around $5 \mathrm{~W} / \mathrm{m}^{2} \mathrm{~s}$ while the radiative heat transfer coefficients varied around $0.5 \mathrm{~W} / \mathrm{m}^{2} \mathrm{~s}$. The variation of the convective heat transfer coefficient between the airflow and glass cover of the solar collector was low and was found to be around $25 \mathrm{~W} / \mathrm{m}^{2}$ s. Figure $8 \mathrm{~b}$ shows that the solar dryer decreases the value of the drying air relative humidity and increases the temperature during sunny days, which leads to a quick decrease in the moisture content of the product, thereby increasing the mass transfer coefficient $\left(\mathrm{h}_{\mathrm{m}}\right)$ during the sunny days as shown in fig Figure $8 \mathrm{c}$. However, the heat transfer coefficient $h_{m}$ varies between $2.5 \times 10^{-7}$ and $2 \times 10^{-6} \mathrm{~m} / \mathrm{s}$.

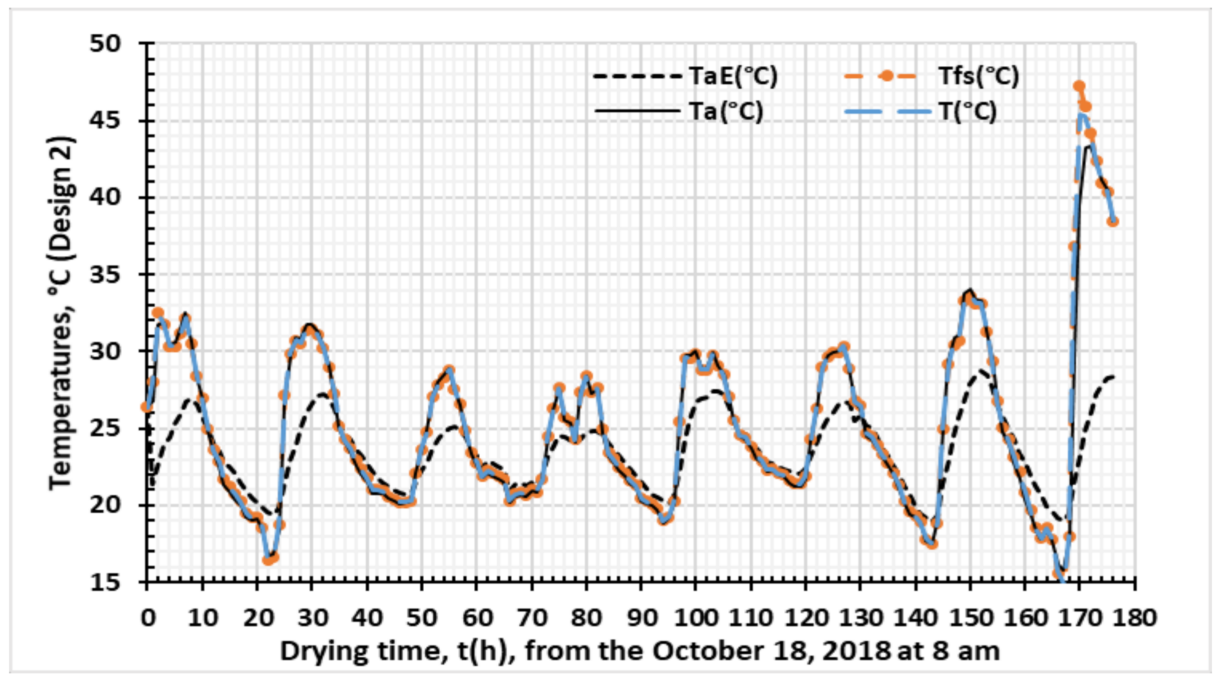

Figure 7. Evolutions of temperatures of ambient air (TaE), drying air (Ta), of the product (T) and airflow air outlet the solar collector (Tfs) in Yamoussoukro, October 2018, design 2.

Figure 9 shows the effects of temperature and humidity gradient on the thickness of the product (Figure 9a) and the absolute value of the drying kinetics (Figure 9b) as the product loses moisture. From the figures, the first hour of drying time showed that the part of the product in contact with the tray is near the equilibrium moisture content. This is as a result of the solar collector raising the temperature of the airflow. During this drying period, the product loses moisture from the surface as it dries, leaving the center or the core wet. Therefore, drying the core of the product takes more time, which always prolongs the drying duration. After $4 \mathrm{~h}$ drying, the moisture content at the core dries from 1.75 to $1 \mathrm{~kg} / \mathrm{kg}$. However, a moisture content of about $0.4 \mathrm{~kg} / \mathrm{kg}$ was achieved at the center after $8 \mathrm{~h}$ of drying. High moisture gradients were observed on the side of the tray while on the opposite side, a low moisture gradient was observed due to the variations of the characteristics of the drying air. The temperature distribution in the thickness of the product is regular and increases during the drying process. Thus, the surfaces dried very quickly due to the low relative humidity values at the surfaces.

Figure $9 \mathrm{~b}$ shows that after $1 \mathrm{~h}$ of drying, the surfaces dried very quickly compared to the center of the product. During the drying, the drying kinetics were lower at the surfaces because of low humidity. The values of absolute drying kinetics are below $1.2 \times 10^{-4} \mathrm{~kg} /(\mathrm{kg} \cdot \mathrm{s})$. 

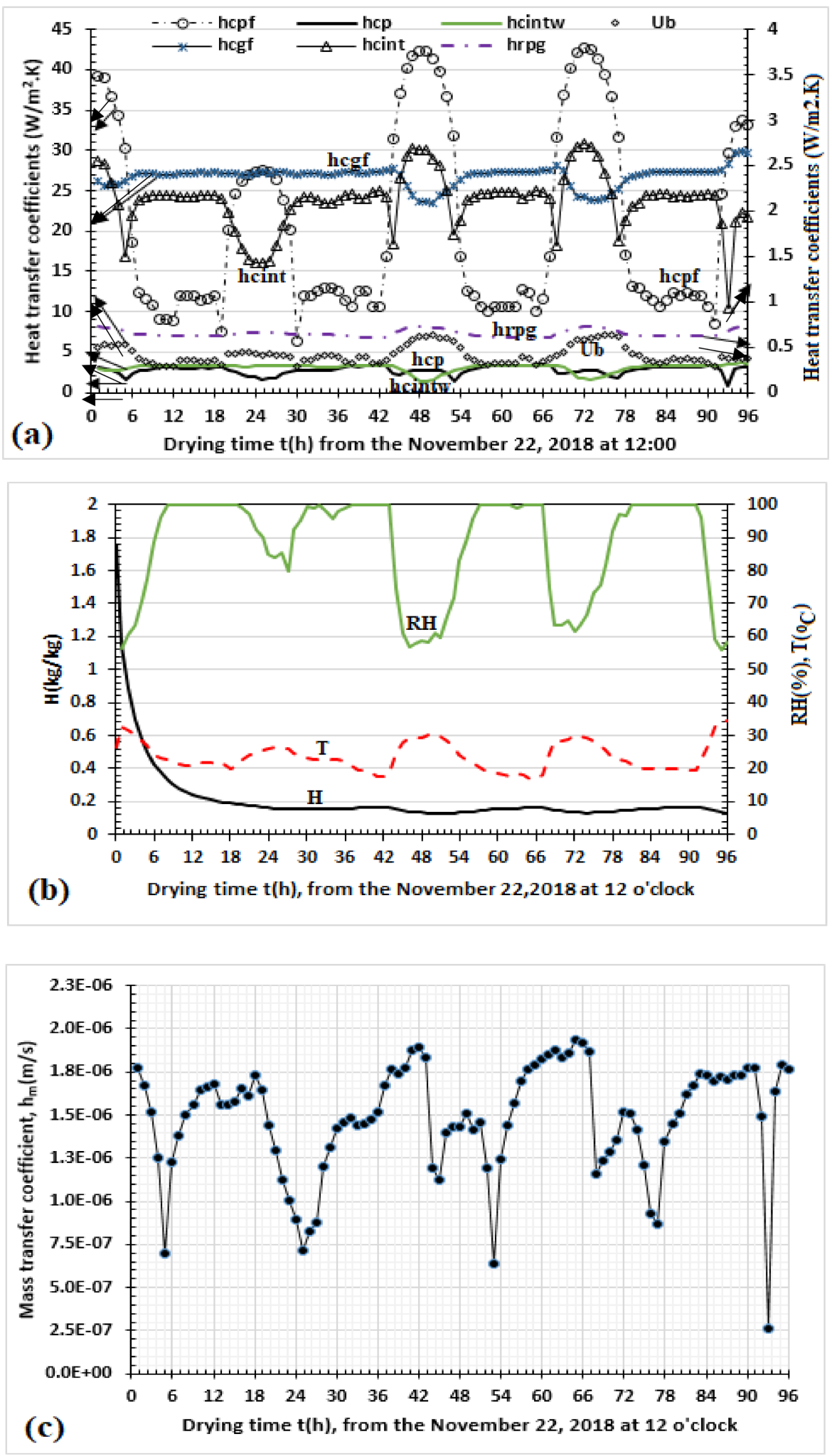

Figure 8. Drying kinetics in Yaoundé (Cameroon) from 22 November 2018, at noon (design 2). Heat transfer coefficients (a), Temperature, relative humidity and moisture content variations (b), mass transfer coefficient $(\mathbf{c})$. 

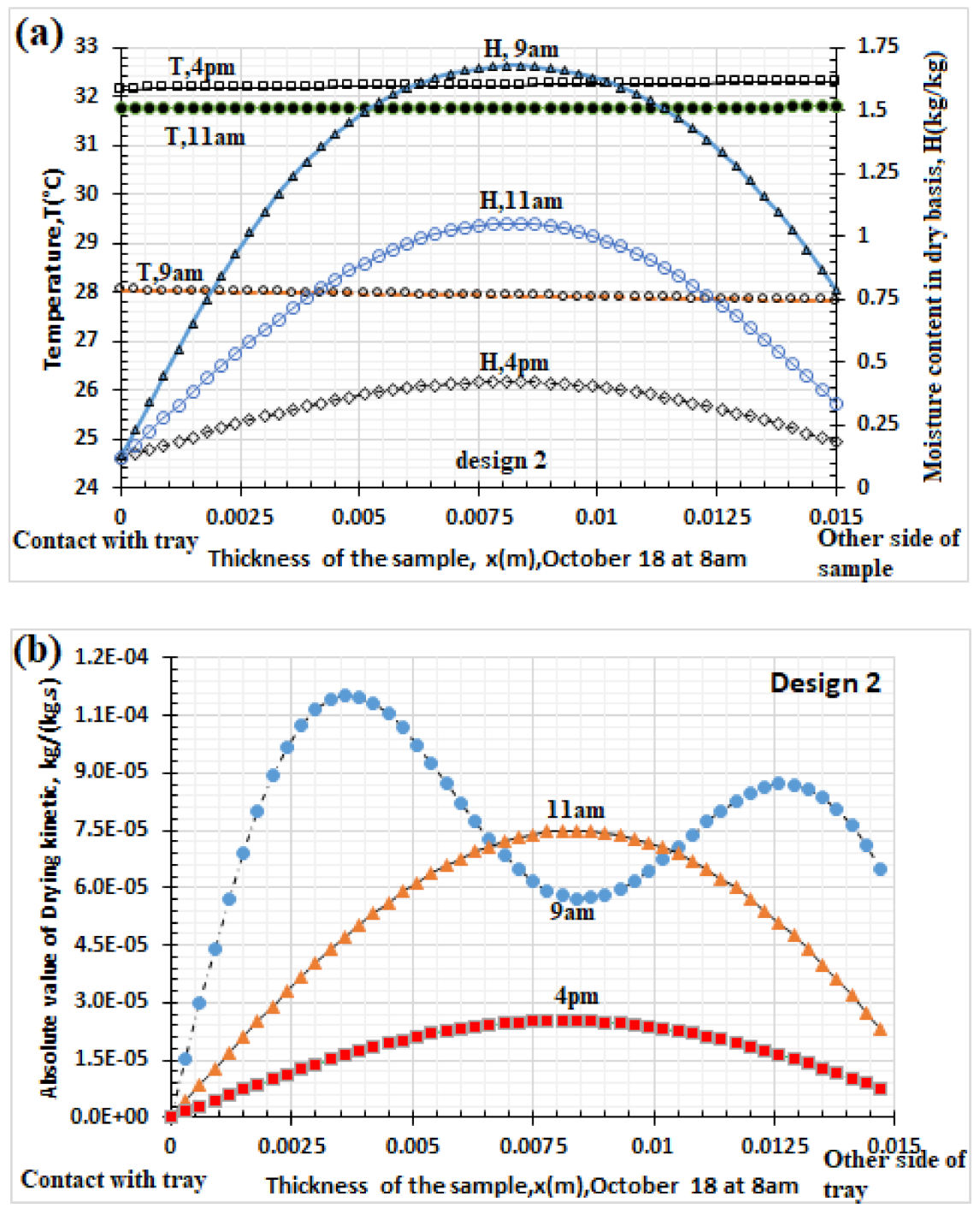

Figure 9. The distribution of the temperature and moisture content in the thickness of the product for 18 October; initial local drying time was 8:00 am at Yaoundé. Temperature and moisture content (a) and drying kinetic (b) using design 2.

\section{Conclusions}

An indirect solar dryer for drying cassava root chips was modelled and experimentally validated. The dryers were operational in Sub-Saharan Africa in natural convection mode with Yaoundé and Yamoussoukro chosen as the towns for validation. A resolution of equations was achieved by finite difference and the 4th order Runge-Kutta methods. Models were proposed for heat and mass transfer using thermophysical properties of cassava roots and the obtained results were satisfactory for all conditions for the environmental condition. The moisture content difference between the experimental and theoretical results was less than $0.2 \mathrm{~kg} / \mathrm{kg}$ dry basis. The model showed that the core of the product takes more time to dry, which always prolongs the drying duration. However, after $4 \mathrm{~h}$ drying, the moisture content at the core dries from 1.75 to $1 \mathrm{~kg} / \mathrm{kg}$ while it took $8 \mathrm{~h}$ of drying to lower it to $0.4 \mathrm{~kg} / \mathrm{kg}$. In addition, the results show that the heat and mass transfer coefficients varied during the night and the day. The variations of the convective heat transfer coefficients between the drying air and the solar dryer are higher than all the heat radiative transfer coefficients. The high and low temperatures as well as the humidity gradient were observed for each drying time. 
Author Contributions: Conceptualization, M.S.-T., A.T.T., and M.C.N.; methodology, M.S.-T. and A.T.T.; software, M.S.-T. and A.T.T.; validation, M.S.-T., A.T.T., and M.C.N.; formal analysis, M.S.-T., A.T.T., and M.C.N.; investigation, M.S.-T., A.T.T., and M.C.N.; resources, M.S.-T., A.T.T., and M.C.N.; data curation, M.S.-T., A.T.T., and M.C.N.; writing—original draft preparation, M.S.-T., A.T.T., and M.C.N.; writing-review and editing, M.S.-T., A.T.T., M.C.N., L.B., M.B.O.A., M.E.M., and Y.R.; visualization, M.S.-T., A.T.T., M.C.N., L.B., M.B.O.A., M.E.M., and Y.R.; supervision, L.B., M.B.O.A., M.E.M., and Y.R.; project administration, M.S.-T. and M.C.N. All authors have read and agreed to the published version of the manuscript.

Funding: This research received no external funding.

Institutional Review Board Statement: Not applicable.

Informed Consent Statement: Not applicable.

Data Availability Statement: Not applicable.

Acknowledgments: M. Simo-Tagne and A. Tagne Tagne acknowledge Romain Rémond of the University of Lorraine (ENSTIB-Epinal/France) for the meteorological data obtained from Meteonorm software. LERMAB is supported by a grant overseen by the French National Research Agency (ANR) as part of the "Investissements d'Avenir" program (ANR-11-LABX-0002-01. Lab of Excellence ARBRE) and is part of ICEEL (Institut Carnot pour l'Energie et l'Environnement en Lorraine).

Conflicts of Interest: The authors declare no conflict of interest.

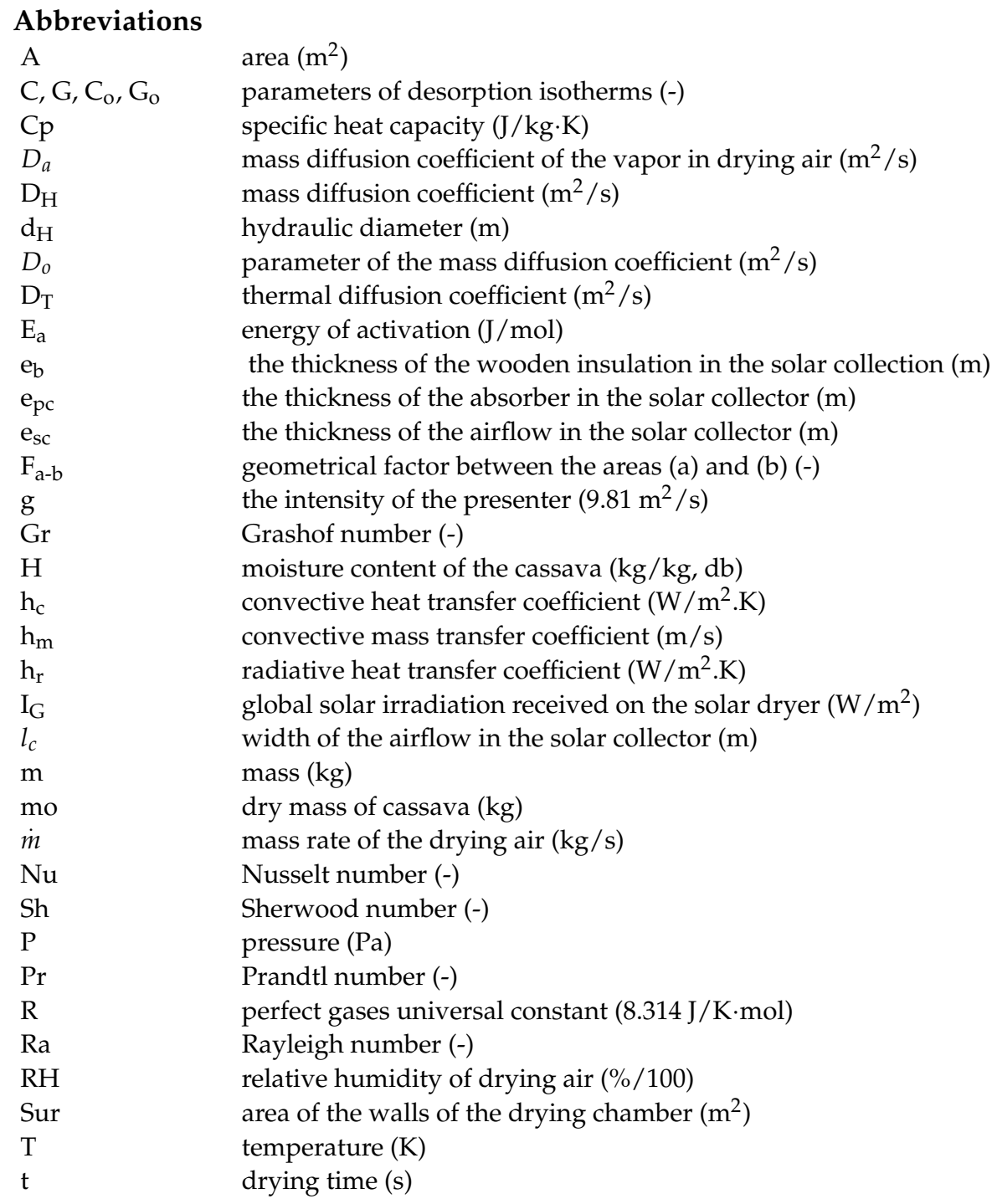




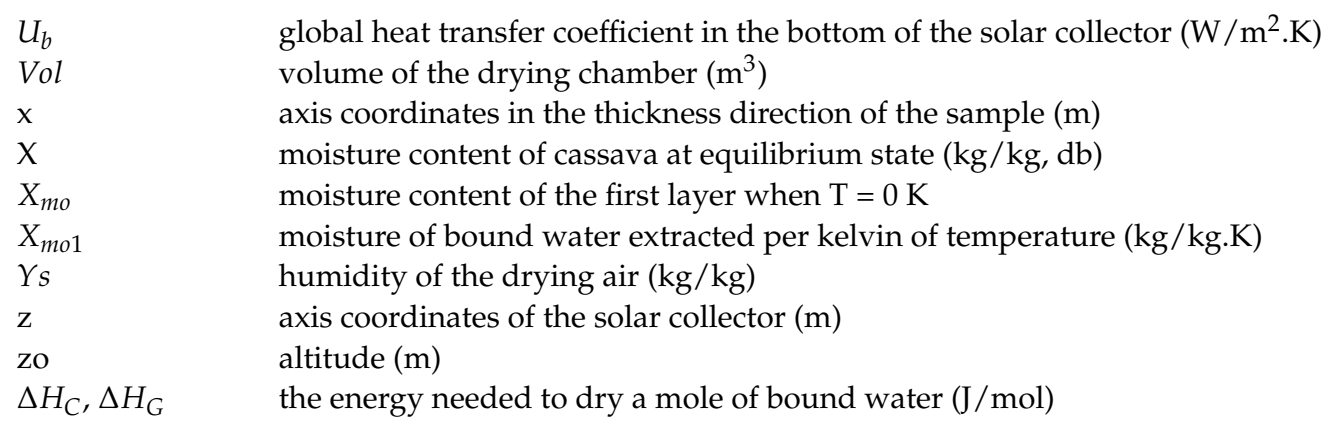

\section{Greek Symbols}

$\lambda$
$\rho$
$\mu_{a}$
$v_{a}$
$\sigma$
$\alpha$
$\alpha_{i}$
$\tau_{i}$
$\rho_{p}$
$\epsilon_{i}$

\section{Subscripts}

a

$\mathrm{aE}, \mathrm{E}$, ext

air

atm

cas

ep

eq

$\mathrm{f}$

fs

$\mathrm{g}$

gc, g

i

$\mathrm{La}$

m

pc

$\mathrm{r}$

sk

v

vsat

w

Index

$i, j$ thermal conductivity $(\mathrm{W} /(\mathrm{m} . \mathrm{K}))$

density $\left(\mathrm{kg} / \mathrm{m}^{3}\right)$

dynamic viscosity of drying air $(\mathrm{Pa} \cdot \mathrm{s})$

kinematic viscosity of the drying air $\left(\mathrm{m}^{2} / \mathrm{s}\right)$

Stephan Boltzmann coefficient $\left(5.67 \times 10^{-8}\right)$

the angle between the solar collector and the horizontal plane $\left(^{\circ}\right)$

solar absorptivity coefficient of component i (-)

solar transmissivity coefficient of component i (-)

solar reflexivity coefficient of the absorber (-)

solar emissivity coefficient of component i (-)

drying air in the drying chamber or solar collector

ambient (exterior space of the solar drying)

air

atmosphere

cassava

surface

equilibrium

airflow in the solar collector

end position of the solar collector when $\mathrm{z}=\mathrm{Z}_{\max }$ (outlet point)

gas (air)

glass cover

the interior of the dryer

lateral part

the first layer of bound water

absorber in the solar collector

roof

sky

vapor

vapor in saturation state

wall

order of discretization scheme (-)

\section{Appendix A. Thermophysical Parameters of the Drying Air}

Appendices See $[2,34,49]$.

Thermal conductivity $(\mathrm{W} /(\mathrm{m} . \mathrm{K})),\left(\mathrm{T}_{\mathrm{a}}\right.$ in $\left.{ }^{\circ} \mathrm{C}\right)$ :

$$
\lambda_{\mathrm{a}}=7.57 \times 10^{-5} \mathrm{~T}_{\mathrm{a}}+0.0242
$$

Heat capacity of dry air $(\mathrm{J} /(\mathrm{kg} . \mathrm{K})),\left(\mathrm{T}_{\mathrm{a}}\right.$ in $\left.{ }^{\circ} \mathrm{C}\right)$ :

$$
\mathrm{C}_{\mathrm{pa}}=1835-0.734 \mathrm{~T}_{\mathrm{a}}
$$


Heat capacity of vapor air $(\mathrm{J} /(\mathrm{kg} \cdot \mathrm{K})),\left(\mathrm{T}_{\mathrm{a}}\right.$ in $\left.{ }^{\circ} \mathrm{C}\right)$ :

$$
\mathrm{C}_{\mathrm{pv}}=999.2+0.1434 \mathrm{~T}_{\mathrm{a}}+1.101 \times 10^{-4} \mathrm{~T}_{\mathrm{a}}{ }^{2}-6.7581 \times 10^{-8} \mathrm{~T}_{\mathrm{a}}{ }^{3}
$$

Dynamic viscosity $(\mathrm{Pa} \cdot \mathrm{s}),\left(\mathrm{T}_{\mathrm{a}}\right.$ in $\left.{ }^{\circ} \mathrm{C}\right)$ :

$$
\mu_{\mathrm{a}}=1.718 \times 10^{-5}+4.620 \times 10^{-8} \mathrm{~T}_{\mathrm{a}}
$$

Mass diffusion coefficient of vapor in air:

$$
\begin{gathered}
\mathrm{D}_{\mathrm{a}}\left(\mathrm{m}^{2} / \mathrm{s}\right)=\frac{2.25 \times 10^{-5}}{\mathrm{P}_{\mathrm{atm}}}\left(\frac{\mathrm{T}_{\mathrm{a}}}{273}\right)^{1.81} \\
\mathrm{P}_{\mathrm{atm}}=101,325-12 \mathrm{zo}+5.2 \times 10^{-4} \mathrm{zo}^{2}
\end{gathered}
$$

where zo in $\mathrm{m}$ is the altitude, $\mathrm{T}_{\mathrm{a}}$ is given in $\mathrm{K}$, and $\mathrm{P}_{\mathrm{atm}}$ in $\mathrm{Pa}$.

The density of the air vapor:

$$
\rho_{\mathrm{g}}\left(\mathrm{kg} / \mathrm{m}^{3}\right)=\frac{353}{\mathrm{~T}_{\mathrm{a}}}
$$

where $T_{a}$ is given in $K$.

\section{Appendix B. Non-Dimensional Numbers}

Prandtl number (-) $\left(\mathrm{T}_{\mathrm{a}}\right.$ in $\left.{ }^{\circ} \mathrm{C}\right)$ :

$$
\operatorname{Pr}=-2.54 \times 10^{-4} \mathrm{~T}_{\mathrm{a}}+0.7147
$$

Grashof number (-) ( $T_{a}$ in $\left.K\right)$ :

$$
\mathrm{Gr}=\frac{\beta \mathrm{gd}_{\mathrm{h}}^{3} \rho_{\mathrm{a}}^{2} \Delta \mathrm{T}}{\mu_{\text {air }}^{2}} ; \beta=\frac{1}{\mathrm{~T}_{\mathrm{a}}}
$$

\section{References}

1. Ndukwu, M.C.; Akani, O.A.; Simonyan, K.J. Nigeria's grain resource structure, and government sustainable policy: A review. Agric. Eng. Int. CIGR J. 2015, 17, 441-457.

2. Simo-Tagne, M.; Ndukwu, M.C.; Zoulalian, A.; Bennamoun, L.; Kifani-Sahban, F.; Rogaume, Y. Numerical analysis and validation of a natural convection mix-mode solar dryer for drying red chilli under variable conditions. Renew. Energy 2020, 151, 659-673. [CrossRef]

3. Ndukwu, M.C.; Manuwa, S.I. Impact of evaporative cooling preservation on the shelf life of fruits and vegetable in South-Western Nigeria. Res. Agric. Eng. 2015, 61, 122-128. [CrossRef]

4. Ndukwu, M.C.; Asoegwu, S.N.; Ahaneku, I.E. Status of research on agricultural machinery development in Nigeria: A case study of cassava tuber processing machineries. Agric. Mech. Asia Afr. Latin Am. 2018, 49, 150-155.

5. Ndukwu, M.C.; Onyenwigwe, D. Development of a motorized parboiled cassava tuber shredding machine. Niger. J. Technol. 2013, 32, 1-6.

6. Egbeocha, C.C.; Asoegwu, S.N.; Okereke, N.A.A. A Review on performance of cassava, peeling machines in Nigeria. Futo J. Ser. 2016, 2, 140-168.

7. Igboayaka, E.C.; Ndukwu, M.C.; Ernest, I.C. A Modelling approach for determining the throughput capacity and energy consumption of a cassava tuber shredder. J. Chin. Adv. Mater. Soc. 2018, 6, 801-816. [CrossRef]

8. Ndukwu, M.C.; Afam, G.; Nwakuba, N.R. Development and optimization of a manual fed cassava root chipper for household cassava processors. Turk. J. Agric. Eng. Res. (TURKAGER) 2020, 1, 283-295. [CrossRef]

9. Ndukwu, M.C.; Ogunlowo, A.S.; Olukunle, O.J. Cocoa bean (Theobroma Cacao L.) drying kinetics. Chil. J. Agric. Res. 2010, 70, 633-639.

10. Sharma, A.; Chen, C.R.; Vu Lan, N. Solar-energy drying systems: A review. Renew. Sustain. Energy Rev. 2009, 13, 1185-1210. [CrossRef]

11. Ndukwu, M.C.; Bennamoun, L. Potential of integrating $\mathrm{Na}_{2} \mathrm{SO}_{4} \cdot 10 \mathrm{H}_{2} \mathrm{O}$ pellets in solar drying system. Dry. Technol. 2018, 36, 1017-1030. [CrossRef] 
12. Anyanwu, C.N.; Oparaku, O.U.; Onyegegbu, S.O.; Egwuatu, U.; Edem, N.I.; Egbuka, K.; Nwosu, P.N.; Sharma, V.K. Experimental investigation of a photo voltaic-powered solar cassava dryer. Dry. Technol. 2012, 30, 398-403. [CrossRef]

13. Simo-Tagne, M. Simple solar dryers adapted to the social, climatic and economic context can help increase the value of tropical timber. ITTO Trop. For. Update 2018, 27, 25-27.

14. Ndukwu, M.C.; Diemuodeke, E.O.; Abam, F.I.; Abada, U.C.; Eke-emezie, N.; Simo-Tagne, M. Development and modelling of heat and mass transfer analysis of a low-cost solar dryer integrated with biomass heater: Application for West African Region. Sci. Afr. 2020, 10, e00615. [CrossRef]

15. Ndukwu, M.C.; Simo-Tagne, M.; Bennamoun, L. Solar drying research of medicinal and aromatic plants: An African experience with assessment of the economic and environmental impact. Afr. J. Sci. Technol. Innov. Dev. 2020, 1-14. [CrossRef]

16. Cadyventures. Available online: https://www.cadyventures.com/product/organic-dried-cassava-chips/ (accessed on 14 February 2021).

17. Istockphoto. Available online: https://www.istockphoto.com/fr/search/2/image?excludenudity=false\&phrase=cassava $\% 20$ roots (accessed on 14 February 2021).

18. Pirasteh, G.; Saidur, R.; Rahman, S.M.A.; Rahim, N.A. A review on development of solar drying applications. Renew. Sustain. Energy Rev. 2014, 31, 133-148. [CrossRef]

19. Fudholi, A.; Sopian, K.; Bakhtyar, B.; Gabbasa, M.; Othman, M.Y.; Ruslan, M.H. Review of solar drying systems with air-based solar collectors in Malaysia. Renew. Sustain. Energy Rev. 2015, 51, 1191-1204. [CrossRef]

20. Hossain, M.Z.; Alam, M.M.; Hossain, M.F.; Sarker, M.S. Performance evaluation of a cabinet solar dryer for drying red pepper in Bangladesh. J. Agric. Eng. 2018, 774, 100-109. [CrossRef]

21. Ren, H.; Ma, Z.; Lin, W.; Fan, W.; Li, W. Integrating photovoltaic thermal collectors and thermal energy storage systems using phase change materials with rotary desiccant cooling systems. Sustain. Cities Soc. 2018, 36, 131-143. [CrossRef]

22. Amer, B.M.A.; Gottschalk, K.; Hossain, M.A. Integrated hybrid solar drying system and its drying kinetics of chamomile. Renew. Energy 2018, 121, 539-547. [CrossRef]

23. Nwakuba, N.R.; Ndukwu, M.C.; Asonye, G.U.; Asoegwu, S.N.; Nwandikom, G.I. Environmental sustainability analysis of a hybrid heat source dryer. Polytechnica 2020, 9-114. [CrossRef]

24. Simo-Tagne, M.; Ndukwu, M.C.; Ndi-Azese, M. Experimental modelling of a solar dryer for wood fuel in Epinal (France). Modelling 2020, 1, 39-52. [CrossRef]

25. Ndukwu, M.C.; Bennamoun, L.; Abam, F.I. Experience of solar drying in Africa: Presentation of designs, operations, and models. Food Eng. Rev. 2018, 10, 211-244. [CrossRef]

26. Bennamoun, L. Reviewing the experience of solar drying in Algeria with presentation of the different design aspects of solar dryers. Renew. Sustain. Energy Rev. 2011, 15, 3371-3379. [CrossRef]

27. Chaudhari, A.D.; Salve, S.P. A review of solar dryer technologies. Int. J. Res. Advent Technol. 2014, 2, $218-232$.

28. Bahnasawy, A.H.; Shenana, M.E. Mathematical model of direct sun and solar drying of some fermented dairy products (Kishk). J. Food Eng. 2004, 61, 309-319. [CrossRef]

29. Bennamoun, L.; Belhamri, A. Numerical simulation of drying under variable external conditions: Application to solar drying of seedless grapes. J. Food Eng. 2006, 76, 179-187. [CrossRef]

30. Bala, B.K.; Woods, J.L. Simulation of the indirect natural convection solar drying of rough rice. Sol. Energy 1994, 53, 259-266. [CrossRef]

31. Ayadi, M.; Zouari, I.; Bellagi, A. Simulation, and performance of a solar drying unit with storage for aromatic and medicinal plants. Int. J. Food Eng. 2015, 11, 597-607. [CrossRef]

32. Lamrani, B.; Khouya, A.; Draoui, A. Energy and environmental analysis of an indirect hybrid solar dryer of wood using TRNSYS software. Sol. Energy 2019, 183, 132-145. [CrossRef]

33. Bentayeb, F.; Bekkioui, N.; Zeghmati, B. Modeling and simulation of a wood solar dryer in a Moroccan climate. Renew. Energy 2008, 33, 501-506. [CrossRef]

34. Simo-Tagne, M.; Bonoma, B.; Bennamoun, L.; Monkam, L.; Leonard, A.; Zoulalian, A.; Rogaume, Y. Modeling of coupled heat and mass transfer during drying of ebony wood using indirect natural convection solar dryer. Dry. Technol. 2019, 37, 1863-1878. [CrossRef]

35. Simo-Tagne, M.; Bennamoun, L.; Léonard, A.; Rogaume, Y. Modeling, numerical simulation and validation of a convective dryer in steady conditions: Case study of tropical woods. Int. J. Model. Simul. 2020, 40, 143-161. [CrossRef]

36. Tieu, Z.A.; Gbaha, P.; Diby, K.A. Étude expérimentale d'un grenier séchoir solaire à convection naturelle: Application au séchage du cacao et du manioc. Afr. Sci. 2019, 15, 80-95.

37. Simo-Tagne, M.; Zoulalian, A.; Rogaume, Y.; Rémond, R.; Bonoma, B. Modélisation des isothermes de sorption, caractérisation des propriétés thermodynamiques et détermination des humidités d'équilibre d'usage des bois tropicaux. Rev. Energies Renouvelables 2016, 19, 79-96.

38. Ajala, A.S.; Ngoddy, P.O.; Olajide, J.O. Sorption isotherms and their fitted equations for dried chips of cassava roots (Manihot Esculenta Crantz; Tme-7 variety) and the resulting isosteric heats of sorption. Food Res. 2020, 4, 703-711. [CrossRef]

39. Baharuddin, N.H.; Mohamed, M.; Abdullah, M.M.A.B.; Muhammad, N.; Rahman, R.; Omar, M.N.; Amini, M.H.M.; Razab, M.K.A.A.; Rizman, Z.I. Potential of cassava root as a raw material for biocomposite development. ARPN J. Eng. Appl. Sci. 2016, 11, 6138-6147. 
40. Fernando, W.J.N.; Low, H.C.; Ahmad, A.L. The effect of infrared on diffusion coefficients and activation energies in convective drying: A case study for banana, cassava and pumpkin. J. Appl. Sci. 2011, 11, 3635-3639. [CrossRef]

41. Ajala, A.S.; Aboiye, A.O.; Popoola, J.O.; Adeyanju, J.A. Drying characteristics and mathematical modelling of cassava chips. Chem. Process Eng. Res. 2012, 4, 1-9.

42. Kuitche, A.; Edoun, M.; Takamte, G. Influence of pre-treatment on drying on the drying kinetic of a local okra (Hibiscus ersculentus) variety. World J. Dairy Food Sci. 2007, 2, 83-88.

43. Simo-Tagne, M.; Zoulalian, A.; Rémond, R.; Rogaume, Y. Mathematical modelling and numerical simulation of a simple solar dryer for tropical wood using a collector. Appl. Therm. Eng. 2018, 131, 356-369. [CrossRef]

44. Incropera, F.P.; Dewitt, D.P.; Bergman, T.L.; Lavine, A.S. Fundamentals of Heat and Mass Transfer; John Wiley and Sons: Hoboken, NJ, USA, 2007; 1070p.

45. Bower, S.M.; Saylor, J.R. A study of the Sherwood-Rayleigh relation for water undergoing natural convection-driven evaporation. Int. J. Heat Mass Transf. 2009, 52, 3055-3063. [CrossRef]

46. Njomo, D. Modelling the heat exchanges in a solar air heater with a cover partially transparent to infrared radiation. Energy Convers. Manag. 1991, 31, 495-503. [CrossRef]

47. Simo-Tagne, M.; Zoulalian, A.; Remond, R.; Rogaume, Y.; Bonoma, B. Modeling and simulation of an industrial indirect solar dryer for iroko wood (Chlorophora excelsa) in a tropical environnement. Maderas Cienc. Tecnol. 2017, 19, 95-112. [CrossRef]

48. Meteonorm. Available online: http:/ / www.meteonorm.com/ (accessed on 24 June 2019).

49. Simo-Tagne, M.; Rogaume, Y.; Zoulalian, A. Modeling and simulation of the drying of the beech timber (Fagus sylvatica) using oscillating regimes. Int. J. Therm. Environ. Eng. 2014, 8, 83-90. 